\title{
KAJIAN PRODUKSI DAN KONSUMSI BERAS PETANI PEMILIK LAHAN DI KECAMATAN PRAYA BARAT KABUPATEN LOMBOK TENGAH
}

\section{THE STUDY ON PRODUCTION AND CONSUMPTION OF FARMERS RICE AS THE OWNER OF THE LAND IN PRAYA DISTRICT OF CENTRAL LOMBOK}

\author{
Winda Sulistiani ${ }^{1 *}$, IGL Parta Tanaya ${ }^{2}$, Asri Hidayati ${ }^{3}$ \\ ${ }^{1}$ Mahasiswa Program Studi Agribisnis Fakultas Pertanian Unram \\ ${ }^{2,3}$ Dosen Program Studi Agribisnis Fakultas Pertanian Unram \\ *E-mail: windasulistiani08@gmail.com
}

\begin{abstract}
ABSTRAK
Penelitian ini bertujuan untuk: (1) Untuk mengetahui jumlah produksi padi/beras petani pemilik lahan di Kecamatan Praya Barat. (2) Mengetahui tingkat rata-rata konsumsi beras keluarga petani pemilik lahan di Kecamatan Praya Barat. (3) Mengetahui pengaruh tingkat produksi beras terhadap konsumsi beras keluarga petani pemilik lahan di Kecamatan Praya Barat. Penelitian ini menggunakan metode penelitian deskriptif dengan jenis data kualitatif dan data kuantitatif. Sedangkan sumber data yang dikumpulkan dalam penelitian ini adalah data primer dan data sekunder. Unit analisis pada penelitian ini adalah petani pemilik lahan yaitu 77 responden yang berada di tiga Desa yaitu Desa Kateng, Desa Penujak dan Desa Batujai atas pertimbangan bahwa ketiga desa tersebut memiliki jumlah petani pemilik lahan terbanyak. Teknik analisis yang digunakan dalam penelitian ini adalah analisis pendapatan, konversi beras, pengkelasan tingkat konsumsi serta analisis OLS regresi linier sederhana dengan bantuan aplikasi SPSS 16.0. Hasil Penelitian menunjukkan bahwa : (1) Jumlah Produksi padi dalam satu kali musim tanam petani pemilik lahan di Kecamatan Praya Barat adalah sebesar 169 ton Gabah Kering Panen atau 152,78 ton Gabah Kering Giling dan jumlah produksi beras adalah 95,879 ton. (2) Rata-rata konsumsi beras petani pemilik lahan di Kecamatan Praya Barat adalah 39,6 Kg/kap/4 bulan atau 118,8 Kg/kap/tahun dan dikatagorikan kedalam kelas konsumsi sedang. (3) Secara parsial tingkat produksi beras tidak signifikan atau tidak berpengaruh nyata terhadap konsumsi beras petani pemilik lahan di Kecamatan Praya Barat Kabupaten Lombok Tengah.
\end{abstract}

Kata kunci: Produksi beras, konsumsi beras, surplus dan defisit.

\section{ABSTRAK}

The purpose of this study is: (1) To find out the amount of rice production, farmers own land in West Praya District. (2) to find out the average level of rice consumption of farmer family land owners in Praya Barat District. (3) to determine the effect of the level of rice production on rice consumption of farmer family land owners in Praya Barat District. This study uses descriptive research methods with types of qualitative data and quantitative data. While the source of data collected in this study are primary data and secondary data. The unit of analysis in this study were landowners, namely 77 respondents in three villages, namely Kateng Village, Penujak Village and Batujai Village on the consideration that the three villages had the highest number of landowners. The analysis technique used in this study is income analysis, rice conversion, classification of consumption levels and simple linear regression OLS analysis with the help of SPSS 16.0 application. Research results show that: (1) The amount of paddy production in one planting season of landowners in West Praya District is 169 tons of Harvested Dry Grain or 152.78 tons of Milled Dry Rice and the amount of rice production is 95.879 tons.(2) The average rice consumption of farmers who own land in West Praya Subdistrict is $39.6 \mathrm{Kg} / \mathrm{cap} / 4$ months or $118.8 \mathrm{Kg}$ / cap / year and is categorized into a moderate consumption class.(3) Partially the level of rice production is not significant or does not significantly affect the rice consumption of farmers who own land in West Praya District, Central Lombok Regency.

Key Words: Rice production, rice consumption, surplus and deficit. 


\section{PENDAHULUAN}

Indonesia merupakan negara agraris yang memiliki lahan pertanian yang sangat luas. Tanaman yang banyak dibudidayakan di Indonesia adalah tanaman padi. Padi merupakan salah satu komoditas pertanian yang banyak dibudidayakan dan sangat kompleks keberadaannya bagi kebutuhan pangan masyarakat Indonesia. Hampir seluruh penduduk Indonesia memenuhi kebutuhan pangannya dari tanaman padi (Utama, 2015).

Di Indonesia pangan sering diidentikkan dengan beras karena jenis pangan ini merupakan makanan pokok paling banyak dikonsumsi. Selain memiliki lahan pertanian yang luas, Penduduk Indonesia juga terkenal sebagai negara yang mengkonsumsi beras tergolong dalam kuantitas besar, yaitu sekitar $140 \mathrm{~kg}$ beras pertahun. (Soemarwoto, 2018). Masalah yang dihadapi sektor pertanian pada tanaman padi (beras) adalah masalah produksi (ketersediaan) beras dan kestabilan harga beras (Septiadi et al. 2016).

Kecamatan Praya Barat yang termasuk dalam lingkar Lombok Selatan merupakan salah satu wilayah penyumbang beras di Provinsi NTB, dimana mayoritas pekerjaan penduduk di wilayah ini adalah petani. Pada tahun 2017 tercatat jumlah petani di Kecamatan Praya Barat adalah 9.537 orang dengan jumlah petani pemilik lahan adalah 9.166 orang yang tersebar di 10 Desa. Petani pemilik lahan adalah petani yang memiliki lahan usaha sendiri dan lahannya tersebut diusahakan atau digarap sendiri oleh petani tersebut (BPS Kabupaten Lombok Tengah, 2018).

Dari sisi permintaan, masyarakat memiliki ketergantungan yang begitu tinggi terhadap komoditas beras. Jumlah permintaan beras selalu meningkat, sementara jumlah produksi beras domestik nilainya berfluktuasi (Septiadi, 2019). Ketersediaan beras di Kecamatan Praya Barat merupakan aspek penting yang harus selalu tercukupi. Megingat rata-rata masyarakat di wilayah ini menjadikan beras sebagai makanan pokok yang setiap hari dikonsumsi. Dengan demikian diharapkan peningkatan pendapatan produksi padi untuk mencukupi kebutuhan konsumsi beras rumah tangga petani, baik petani pemilik lahan maupun petani penggarap. Pemenuhan kebutuhan akan pangan beras rumah tangga di Kecamatan Praya Barat pastinya akan berbeda-beda, karena masyarakat di Kecamatan Praya Barat mempunyai karakteristik yang berbeda-beda seperti, jumlah produksi beras yang dihasilkan, pendapatan, pendidikan, jumlah anggota keluarga antara rumah tangga yang satu dengan rumah tangga yang lainnya maupun perilaku dan kebiasaan (sosial budaya). Sehingga dalam memenuhi kebutuhan pangannya dan penentuan jumlah pangan yang akan dikonsumsi juga pasti berbeda. Sehingga tujuan dari penelitian ini adalah (1) untuk mengetahui jumlah produksi padi/beras petani pemilik lahan di Kecamatan Praya Barat. (2) mengetahui rata-rata tingkat konsumsi beras keluarga petani pemilik lahan di Kecamatan Praya Barat dan (3) mengetahui pengaruh tingkat produksi beras terhadap konsumsi beras keluarga petani pemilik lahan di Kecamatan Praya Barat.

\section{METODE PENELITIAN}

Metode yang digunakan dalam penelitian ini adalah metode deskriptif sedangkan pengumpulan data dilakukan dengan teknik survei atau wawancara langsung. Unit analisis dalam penelitian ini adalah petani pemilik lahan yang menanam padi di Kecamatan Praya Barat Kabupaten Lombok Tengah. Penelitian in dilakukan di 3 (tiga) desa yaitu Desa Kateng, Desa Penujak dan Desa Batujai dengan teknik purposive sampling atas pertimbangan bahwa ketiga desa tersebut memiliki jumlah petani pemilik lahan terbanyak. Penentuan jumlah responden dilakukan secara quota sampling yaitu sebanyak 77 orang petani pemilik lahan dengan rincian 24 responden di Desa Kateng, 26 responden di Desa Penujak dan 26 responden di Desa Batujai 27 responden. Jenis data yang digunakan adalah data kuantitatif dan data kualitatif, sumber data dari data primer dan data sekunder. Variabel dan cara pengukuran dalam penelitian ini adalah (a) biaya dan pendapatan usahatani padi petani pemilik lahan (b) produksi yang dihasilkan petani pemilik lahan dalam satu kali proses produksi/panen yang dinyatakan dalam kg (c) jumlah konsumsi yang dilakukan petani pemilik lahan dalam satu kali musim tanam yang dinyatakan dalam $\mathrm{kg}$.

Data dianalisis secara deskriptif. Adapun rumus yang digunakan meliputi rumus Pendapatan usahatani menggunakan analisis $\mathrm{Pd}=\mathrm{TR}-\mathrm{TC}$;

dimana;

$\mathrm{Pd}=$ pendapatan usahatani $(\mathrm{Rp})$;

$\mathrm{TR}=$ total penerimaan $(\mathrm{Rp})$; dan

$\mathrm{TC}=$ total biaya produksi $(\mathrm{Rp})$.

Penerimaan usahatani menggunakan analisis $\mathrm{TR}=\mathrm{Q} \times \mathrm{P}$;

dimana;

$\mathrm{TR}=$ penerimaan $(\mathrm{Rp})$;

$\mathrm{Q}=$ jumlah produksi $(\mathrm{Kg})$; dan

$\mathrm{P}=$ harga produk $(\mathrm{Rp})$.

Biaya produksi $\mathrm{TC}=\mathrm{FC}+\mathrm{VC}$;

dimana;

$\mathrm{TC}=$ total biaya produksi $(\mathrm{Rp})$; 
$\mathrm{FC}=$ total biaya tetap $(\mathrm{Rp})$

$\mathrm{VC}=$ total biaya variabel.

Produksi beras menggunakan angka konversi beras yaitu 62,76\%. Angka 62,74\% mengartikan bahwa tiap $100 \mathrm{~kg}$ gabah kering giling (GKG) akan menghasilkan 62,74 kg beras. Tingkat konsumsi beras dikelaskan menjadi tiga kelas, yaitu kelas tinggi, sedang, dan rendah. Dan analisis data yang digunakan untuk mengetahui pengaruh tingkat produksi padi adalah analisis OLS regresi linier berganda dengan bantuan aplikasi SPSS 16.0 dimana variabel dependent yang digunakan adalah jumlah konsumsi (Y), sedangkan variabel independent dalam penelitian ini adalah pendapatan (X1), harga beras (X2) dan jumlah anggota keluarga (X3).

\section{HASIL DAN PEMBAHASAN}

\section{Karakteristik Responden}

\section{Umur}

Umur merupakan salah satu faktor penting dalam usahatani. Kemampuan fisik dalam bekerja maupun semangat seorang petani dalam mengelola usahatani sangat dipengaruhi oleh umur. Berdasarkan hasil jawaban kuisioner yang diberikan oleh responden, maka diperoleh data sebagai berikut:

Tabel 3.1 Persentase Responden Berdasarkan Umur

\begin{tabular}{rrr}
\hline Umur (tahun) & Jumlah responden & Persentase \\
\hline $15-24$ & 0 & $0,00 \%$ \\
$25-34$ & 9 & $11,7 \%$ \\
$35-44$ & 20 & $25,9 \%$ \\
$45-54$ & 24 & $31,2 \%$ \\
$55-64$ & 11 & $14,3 \%$ \\
$\geq 65$ & 13 & $16,9 \%$ \\
\hline Total & 77 & $100 \%$ \\
\hline
\end{tabular}

Sumber: Data primer diolah, 2019

Berdasarkan tabel diatas dapat dilihat bahwa petani pemilik lahan paling muda berusia 25-34 tahun sedangkan petani pemilik lahan yang paling tua berusia lebih dari 65 tahun. Rata-rata umur responden adalah 45-54 tahun. Pada penjabaran usia diatas dapat dikatagorikan bahwa rata rata petani pemilik lahan di Kecamatan Praya Barat tergolong dalam usia produktif seorang manusia dalam bekerja. Usia produktif seorang manusia dalam bekerja adalah 15 - 64 tahun (Soekartawi, 2002).

\section{Jumlah Anggota Keluarga}

Tabel 3.2. Persentase Responden Jumlah Aggota Keluarga

\begin{tabular}{rrr}
\hline Jumlah Anggota & Jumlah responden & Persentase \\
Keluarga (orang) & & \\
\hline $1-2$ & 12 & $15,6 \%$ \\
$3-4$ & 41 & $53.2 \%$ \\
$5-6$ & 20 & $26 \%$ \\
$>6$ & 4 & $5,2 \%$ \\
\hline Total & 77 & $100 \%$ \\
\hline
\end{tabular}

Sumber: Data Primer Diolah, 2019

Berdasarkan tabel diatas jumlah anggota keluarga terbanyak adalah 3-4 orang jumlah anggota keluarga dengan jumlah responden 41 orang atau 53,2\%. Sedangkan jumlah anggota keluarga terkecil adalah lebih dari 6 dengan jumlah responden 4 orang atau 5,2\%.

Ilyas (1998) menyatakan bahwa jumlah tanggungan keluarga yang berkisar antara $1-2$ orang tergolong dalam keluarga kecil, 3-4 orang tergolong dalam keluarga sedang, sedangkan untuk keluarga yang tanggunggannya lebih dari 5 orang termasuk dalam golongan keluarga besar. Sehingga dapat ditarik kesimpulan berdasarkan kriteria yang dijelaskan oleh Ilyas (1998) rata-rata jumlah anggota keluarga petani pemilik lahan di Kecamatan Praya Barat tergolong dalam keluarga sedang.

\section{Biaya Produksi dan Pendapatan Petani pemilik Lahan di Kecamatan Praya Barat}

Total biaya produksi yang dikeluarkan pada usahatani padi merupakan penambahan dari biaya variabel dengan biaya tetap yang. Sementara pendapatan merupakan hasil atau nilai dari penerimaan yang telah dihasilkan dikurangi dengan seluruh biaya yang dikeluarkan. Rata-rata biaya produksi dan pendapatan yang diperoleh petani pemilik lahan di Kecamatan Praya Barat disajikan dalam tabel 2. berikut: 
Tabel 2. Rata-rata Biaya Produksi dan Pendapatan per Luas Lahan Garapan Usahatani Padi di Kecamatan Paraya Barat

\begin{tabular}{llrr}
\hline No & Uraian & Nilai (Rp) & Rata-rata/LLG \\
& & & 0,418 \\
\hline 1 & Luas Lahan (Ha) & & \\
2 & Biaya Produksi & 298.461 .900 & $3.876 .128,5$ \\
& Biaya Variabel & 24.729 .990 & $321.168,7$ \\
& Biaya Tetap & 323.191 .890 & 4.197 .297 .3 \\
& Total Biaya Produksi & 676.000 .000 & 8.779 .220 .8 \\
3 & Penerimaan & 352.808 .110 & 4.581 .923 .5 \\
4 & Pendapatan & & \\
\hline
\end{tabular}

Sumber: Data Primer Diolah 2019

Tabel 3.1 menunjukkan bahwa rata-rata total biaya produksi selama satu kali musim tanam di Kecamatan Praya Barat sebesar Rp. 4.197.297.3/LLG atau sebesar Rp. 10.043.253/Ha. Rata-rata pendapatan yang diterima petani pemilik lahan di Kecamatan Praya Barat adalah sebesar Rp. 4.581.923.5/LLG atau sekitar Rp. 10.963.583.3/Ha dalam satu kali musim tanam yang dihitung dari pengurangan rata-rata nilai produksi yang diterima yaitu sebesar Rp. 8.779.220,8/LLG atau sebesar Rp. 21.006.837/Ha dengan rata-rata biaya produksi sebesar Rp. 4.197.297.3/LLG atau sebesar Rp. 10.043.253/Ha.

\section{Kajian Produksi dan Konsumsi Beras Petani Pemilik Lahan di Kecamatan Praya Barat}

Dalam penelitian ini produksi beras yang dimaksud adalah banyaknya jumlah pendapatan gabah kering giling yang diterima petani pemilik lahan di Kecamatan Praya Barat dan dikonversikan ke beras, sehingga produksi beras petani pemilik lahan mencapai 169 ton GKP (Gabah Kering Panen) atau 152,78 ton GKG (Gabah Kering Giling) dan jika dikonversikan menjadi beras, petani pemilik lahan menghasilkan 95,879 ton beras dalam satu kali musim tanam atau setara dengan Rp. 767.031.992 dengan rata-rata Rp. 9.961.454,4/LLG.

Di Kecamatan Praya Barat, rata-rata masyarakat menanam padi 2 kali dalam satu tahun, sehingga siklus menanam padi didaerah penelitian adalah 2 kali setahun, jika dihitung produksi beras di Kecamatan Praya Barat secara non siklus maka akan menghasilkan produksi beras sebesar $2.490 \mathrm{Kg} / \mathrm{LLG}$ atau $5.959 \mathrm{Kg} / \mathrm{Ha}$ dalam satu tahun. Jika dihitung secara umum atau secara keseluruhan dengan non siklus maka di Kecamatan Praya Barat akan menghasilkan beras dalam satu tahun adalah $57.254 .072 \mathrm{Kg} / \mathrm{Ha} /$ tahun yang dihasilkan dari perhitungan luas areal panen dikalikan yaitu 9.608 Ha dengan jumlah produksi beras perHa Pertahun yaitu 5.959 $\mathrm{Kg} / \mathrm{Ha}$.

Diliahat dari luas lahan garapan yaitu 0,418 Ha, maka produktivitas padi di Kecamatan Praya Barat ini tergolong dalam kelas "klaster 2" lumbung pangan nasional yaitu luas panen rendah dengan jumlah produksi sedang yaitu 51,52 kwintal/Ha pertahun (Roza dan Tamara, 2016). Kajian produksi dan konsumsi beras petani pemilik lahan dapat dilihat pada Tabel 3.2 dan 3. berikut:

Tabel 3. Kajian Produksi Beras Petani Pemilik Lahan di Kecamatan Praya Barat Dalam Satu Kali Musim Tanam

\begin{tabular}{|c|c|c|c|c|c|c|}
\hline No & Uraian & Fisik & $\begin{array}{l}\text { Harga } \\
(\mathrm{RP} / \mathrm{Kg})\end{array}$ & $\begin{array}{l}\text { Nilai } \\
\text { (Rp) }\end{array}$ & $\begin{array}{l}\text { Rata-rata } \\
\text { Fisik }\end{array}$ & $\begin{array}{l}\text { Rata-rata Nilai } \\
\text { (Rp) }\end{array}$ \\
\hline 1 & $\begin{array}{l}\text { Produksi GKP } \\
\text { (Ton) }\end{array}$ & 169 & 4.000 & 676.000 .000 & $2.194,8$ & $8.779 .220,8$ \\
\hline 2 & $\begin{array}{l}\text { Produski GKG } \\
\text { (Ton) }\end{array}$ & 152,78 & 5.000 & 763.900 .000 & $1.984,2$ & $9.920 .779,2$ \\
\hline 3 & $\begin{array}{l}\text { Produksi Beras } \\
(\mathrm{Kg})\end{array}$ & 95,879 & 8.000 & 767.031 .992 & 1.245 .2 & 9.961 .454 .4 \\
\hline & $\begin{array}{l}\text { Luas Lahan } \\
\text { (Ha) }\end{array}$ & & & & & 0,418 \\
\hline
\end{tabular}

Sumber: Data Primer Diolah 2019

Tabel 4. Kajian Konsumsi Beras Petani Pemilik Lahan di Kecamatan Praya Barat

\begin{tabular}{|c|c|c|c|c|c|}
\hline No & Uraian & $\begin{array}{l}\text { Jumlah } \\
\text { (Kg) }\end{array}$ & $\begin{array}{l}\text { Rata-rata } \\
(\mathrm{Kg})\end{array}$ & $\begin{array}{l}\text { Jumlah } \\
\text { Kg/Kapita }\end{array}$ & $\begin{array}{l}\text { Rata-rata } \\
\text { Kg/Kapita }\end{array}$ \\
\hline 1 & 1 hari & 117,8 & 1,5 & 30,95 & 0,41 \\
\hline 2 & 4 Bulan (1 kali musim tanam) & 14.130 & 183,5 & $3.719,3$ & 48,3 \\
\hline 3 & 1 Tahun & 42.390 & 550,5 & 11.158 & 145 \\
\hline
\end{tabular}

Sumber: Data Primer Diolah 2019

Sulistiani, W., Tanaya, IGL. P., dan Hidayati, A. 
Berdasarkan tabel 4.10 diatas di ketahui bahwa rata-rata konsumsi beras petani pemilik lahan di Kecamatn Praya Barat Kabupaten Lombok tengah dalam sehari adalah 1,5 Kg atau 0,41 Kg/Kap/Hari, rata-rata konsumsi beras selama empat bulan (satu kali musim tanam) adalah 183,5 Kg atau 48,3Kg/Kap/4 bulan sedangkan rata-rata konsumsi beras selama satu tahun adalah $101.430 \mathrm{Kg}$ atau $145 \mathrm{Kg} / \mathrm{Kap} / \mathrm{tahun}$.

Menurut (Soemarwoto, 2018) rata-rata konsumsi beras masyarakat Indonesia dalam satu tahun adalah $140 \mathrm{Kg}$ perkapita dan tergolong dalam konsumsi beras terbesar di dunia. Namun pada penelitian ini rata-rata konsumsi petani pemilik lahan di Kecamatan Praya Barat Kabupaten Lombok Tengah lebih besar $5 \mathrm{Kg}$, yaitu $145 \mathrm{Kg} / \mathrm{kapita} /$ tahun. Sehingga kondisi rata-rata konsmusi beras petani pemilik lahan di Kecamatan Praya Barat Kabupaten Lombok Tengah selama satu tahun tergolong dalam kuantitas yang sangat besar.

Sementara itu tingkat konsumsi beras Petani Pemilik Lahan di Kecamatan Praya Barat dikatagorikan kedalam kelas sedang dengan jumlah konsumsi rata-rata $0.33 / \mathrm{Kg} / \mathrm{Kap} / \mathrm{hari}$ atau $39,6 / \mathrm{Kg} / \mathrm{kap} / \mathrm{satu} \mathrm{kali}$ musim tanam atau 118,8/Kg/kap/tahun. Tingkat konsumsi beras petani pemilik lahan dapat dilihat pada Tabel 5 . berikut:

Tabel 5. Rata-rata Pengkelasan Konsumsi Beras Petani Pemilik Lahan di Kecamatan Praya Barat Dalam Satu Kali Musim Tanam

\begin{tabular}{|c|c|c|c|c|c|c|}
\hline Kelas & $\begin{array}{l}\text { Jumlah } \\
\text { Konsumsi } \\
\text { Hari (Kg) }\end{array}$ & $\begin{array}{l}\text { Jumlah } \\
\text { Responden } \\
\text { (orang) }\end{array}$ & $\begin{array}{l}\text { Rata-rata/ } \\
\text { kap/ } \\
\text { Hari (Kg) }\end{array}$ & $\begin{array}{l}\text { Rata- } \\
\text { rata/ } \\
\text { kap/ } \\
\text { 4bulan } \\
\text { (Kg) }\end{array}$ & $\begin{array}{l}\text { Rata-rata/ } \\
\text { kap/ } \\
\text { Tahun (Kg) }\end{array}$ & $\begin{array}{l}\text { Presentase } \\
(\%)\end{array}$ \\
\hline Tinggi & $260-360$ & 10 & 0.14 & 16,8 & 50,4 & $13 \%$ \\
\hline Sedang & $160-259$ & 37 & 0,33 & 39,6 & 118,8 & $48,1 \%$ \\
\hline Rendah & $60-159$ & 30 & 0.13 & 15,6 & 46,8 & $38,9 \%$ \\
\hline Total & & 77 & & & & $100 \%$ \\
\hline
\end{tabular}

Sumber: Data Primer Diolah 2019

Pada tahun 2017 tercatat jumlah penduduk di Kecamatan Praya Barat adalah 75.166 jiwa. Jika dihitung jumlah konsumsi beras dengan pendekatan $145 \mathrm{~kg} / \mathrm{kapita} /$ tahun maka total konsumsi beras penduduk Kecamatana Praya Barat adalah 10.899.070 Kg/tahun, nilai ini didapat dari perhitungan jumlah penduduk dikalikan dengan jumlah konsumsi beras yaitu $145 \mathrm{Kg} / \mathrm{kap} / \mathrm{thn}$. Sedangkan untuk petani pemilik lahan jumlah konsumsi beras selama satu tahun setelah dikalikan dengan jumlah konsumsi beras dengan jumlah rata-rata perumah tangga yaitu 4 orang adalah $580 \mathrm{Kg}$ /tahun.

Berdasarkan penjabaran tabel 3, 4 dan penjabaran perhitungan diatas dapat ditarik kesimpulan bahwa produksi beras di Kecamatan Praya Barat mengalami surplus, hal ini dapat dilihat dari rata-rata jumlah produksi beras yang dihasilkan petani pemilik lahan dalam satu kali musim tanam yaitu sebesar 1.245,2 $\mathrm{Kg} / \mathrm{LLG}$ atau $2979,4 \mathrm{Kg} / \mathrm{Ha}$ yang jika dihitung secara non siklus menghasilkan produksi beras sebesar 57.254.072 $\mathrm{Kg} / \mathrm{Ha} /$ tahun dibandingkan dengan jumlah rata-rata konsumsi beras yang lebih sedikit selama satu tahun yang dilakukan oleh penduduk Kecamatan Praya Barat yaitu sebesar 10.899.070 Kg pertahun dengan jumlah konsumsi 145/Kg/kapita/tahun, sedangkan untuk petani pemilik lahan saja jumlah konsumsi beras selama setahun adalah $580 \mathrm{Kg}$ /tahun. Oleh karena itu, dengan angka konsumsi beras di Kecamatan Praya Barat $10.899 .070 \mathrm{Kg} / \mathrm{Ha} /$ tahun, maka diketahui surplus beras jika dihitung secara non siklus mencapai 47 juta $\mathrm{Kg}$. Sehingga kebutuhan beras petani pemilik lahan maupun penduduk Kecamatan Praya Barat dapat dipenuhi oleh hasil produksi petani pemiliki lahan itu sendiri dan wilayah penelitian tidak perlu mengimpor beras dari wilayah lain karena wilayah ini aman dari defisit atau kekurangan beras.

\section{Faktor-Faktor yang mempengaruhi Konsumsi Beras Petani Pemilik Lahan di Kecamatan Praya Barat}

Faktor-faktor yang diduga mempengaruhi konsumsi beras petani pemilik lahan yaitu tingkat produksi beras (X1) dan jumlah anggota keluarga (X2). Variabel-variabel tersebut akan dianalisis dengan menggunakan analais OLS regresi linier berganda.

\section{Hasil Uji F}

Uji F dilakukan untuk melihat ada tidaknya pengaruh variabel-variabel indevendent (tingkat produksi beras dan jumlah anggota keluarga) terhadap variabel dependent (konsumsi) secara bersama-sama. Berdasarkan tabel $\mathrm{F}$ dengan taraf nyata 0.05 diketahui bahwa $\mathrm{F}$ hitung 14,804 $>\mathrm{F}$ tabel 3,12 yang artinya variabel independent seperti variabel pendapatan usahatani, jumlah anggota keleuarga dan harga beras bersama-sama mempengaruhi konsumsi beras petani pemilik lahan di Kecamatan Praya Barat.

\section{Hasil Uji $t$}


Uji t atau uji statistik secara parsial yaitu untuk mengetahui apakah suatu variabel atau masing-masing variabel independent signifikan (berpengaruh nyata) atau tidak terhadap konsumsi beras petani pemilik lahan.

\section{a. Tingkat Produksi beras}

Nilai t hitung sebesar 1,293 < dari t tabel sebesar 1,66543 dengan nilai probabilitas 0,200 dan lebih besar dari taraf nyata 0,05 yang artinya variabel pendapatan ushatani tidak signifikan atau tidak berpengaruh terhadap penambahan jumlah konsumsi beras petani pemilik lahan di Kecamatan Praya Barat Kabupaten Lombok Tengah.

Produksi beras adalah jumlah produksi yang dihasilkan petani pemilik lahan selama satu kali musim tanam yang didapatkan dari konversi Gabah Kering Giling (GKG) pada 62,74 \% yang artinya setiap $100 \mathrm{~kg}$ GKG akan menghasilkan $62,74 \mathrm{~kg}$ beras. Dalam penelitian ini terdapat 77 responden petani pemilik lahan yang tersebar di Kecamatan Praya Barat dengan jumlah produksi beras yang didapatkan petani pemilik lahan di Kecamatan Praya Barat Kabupaten Lombok tengah dalam satu kali musim tanam adalah 1.245 kg/LLG atau $2.979 \mathrm{Kg} / \mathrm{Ha}$. Meskipun produksi beras yang dihasilakn cukup tinggi namun tidak memberi pengaruh terhadap jumlah konsumsi beras.

\section{b. Jumlah Anggota Keluarga}

Nilai t hitung sebesar 5,024 > t tabel sebesar 1,66543 dan nilai probabilitas 0,000 lebih kecil dari nilai tarafnyata 0,05 yang artinya jumlah anggota keluarga signifikan atau berpengaruh nyata terhadap jumlah konsumsi beras petani pemilik lahan pada $1 \%$ atau pada taraf nyata $99 \%$.

Jumlah anggota keluarga adalah semua orang yang biasanya bertempat tinggak disuatu rumah tangga (suami, istri, anak, menantu, cucu, orangtua atau mertua, dan keluarga lain) baik yang berada dirumah maupun yang sementara tidak ada dirumah. Jumlah anggota keluarga sangat menentukan jumlah konsumsi beras. semakin banyak anggota keluarga berarti semakin banyak pula jumlah kebutuhan keluarga yang harus dipenuhi. Begitupula sebaliknya. Semakin sedikit anggota keluarga semakin sedikit pula kebutuhan yang harus dipenuhi keluarga. Sehingga dalam keluarga yang jumlah anggota keluarganya banyak, akan diikuti oleh banyaknya jumlah kebutuhan atau konsumsi yang harus dipenuhi.

Total jumlah anggota keluarga dalam penelitian ini adalah 302 orang dengan rata-rata 3,9. Hasil penelitian di Kecamatan Praya Barat ini sejalan dengan penelitian Iriyanti (2017) yang menyatakan bahwa peningkatan jumlah anggota rumah tangga akan diikuti oleh peningkatan konsumsi pangan beras atau sebaliknya dengan dengan penurunan jumlah anggota rumah tangga akan diikuti oleh penurunan konsumsi beras.

\section{c. Koefisien Detrminasi}

Koefisien determinasi $\mathrm{R}^{2}$ digunakan untuk mengetahui berapa persen variasi variabel dependent dapat dijelaskan oleh variasi variabel independent. Berdasarkan tabel diatas, diperoleh koefisien determinasi $\left(\mathrm{R}^{2}\right)$ sebesar 0,266 atau 26,6\%. Hal ini menunjkkan bahwa 26,6\% mampu menjelaskan konsumsi beras petani pemilik lahan di Kecamatan Praya Barat Kabupaten Lombok Tengah dipengaruhi oleh variabel produksi beras dan jumlah anggota keluarg. Sedangkan 73,4\% dipengruhi oleh variabel lain diluar model atau tidak dimasukkan dalam penelitian ini.

\section{Faktor-Faktor yang Mempengaruhi Konsumsi Beras di Kecamatan Praya Barat}

Data yang digunakan untuk mengetahui faktor-faktor yang mempengaruhi konsumsi beras secara umum di Kecamatan Praya Barat Kabupaten Lombok Tengah adalah data 10 tahun terakhir dengan variabel independent konsumsi (Y) dan variabel dependen adalah jumlah produksi beras (X1), jumlah penduduk (X2) dan harga beras (X3).

1. Uji F

Berdasarkan analisa data 10 tahun terakhir yang telah dilakukan, variabel independent seperti variabel jumlah penduduk, produksi beras dan harga beras bersama-sama tidak mempengaruhi konsumsi beras di Kecamatan di Kecamatan Praya Barat dengan taraf nyata 0,05 karena nilai F hitung $(1.57)<\mathrm{F}$ tabel $(8,94)$.

2. Uji t

Dengan uji statistik secara parsial yaitu untuk mengetahui apakah suatu variabel atau masing-masing variabel tersebut signifikan (berpengaruh nyata) atau tidak terhadap konsumsi beras secara umum di Kecamatan Praya Barat.

Dari hasil OLS regresi linier berganda diatas dapat disusun persamaan regresi sebagai berikut:

$\mathrm{Y}=-4.357-2.933(\mathrm{X} 1)+0.120(\mathrm{X} 2)+0.000(\mathrm{X} 3)$

Variabel produksi beras tidak berpengaruh terhadap konsumsi beras di Kecamatan Praya Barat. Hal ini diakibatkan oleh nilai t hitung sebesar $-1.099<$ dari t tabel sebesar 1,84958 dengan nilai probabilitas 0,314 dan 
lebih besar dari taraf nyata 0,05 . Produksi beras adalah jumlah beras yang dihasilakan saat melakukan ushatani padi yang sudah di konversikan. Produksi beras di Kecamatan Praya Barat selama 10 mengalami peningkatan. Rata-rata jumlah produktivitas beras di kecamatan Praya Barat adalah 1.797 ton/Ha.

Variabel jumlah penduduk berpengaruh terhadap jumlah konsumsi beras di Kecamatan Praya Barat. Hal ini dapat dilihat dari nilai $t$ hitung sebesar 2,0163 $>\mathrm{t}$ tabel sebesar 1,84958 dengan nilai probabilitas 0,00 lebih kecil dari nilai taraf nyata $(0,01)$, yang artinya jumlah penduduk signifikan atau berpengaruh nyata terhadap jumlah konsumsi beras di Kecamatan Praya Barat pada 1\% atau pada taraf nyata 99\%. Hasil ini sejalan dengan penelitian yang dilakukan Septiadi (2019a) yang menunjukkan bahwa variabel jumlah penduduk berpengaruh signifikan terhadap variabel permintaan beras untuk konsumsi, dibuktikan dengan p-value 0.0003 lebih kecil dari nilai taraf signifikansinya sebesar 5 persen.

Variabel harga beras tidak mempengaruhi jumlah konsumsi beras di Kecamatan Praya Barat. Hal ini dapat dilihat pada nilai $\mathrm{t}$ hitung sebesar $-2,648<\mathrm{t}$ tabel sebesar 1,84958 dengan nilai probabilitas 0,038 lebih besar dari nilai taraf nyata 0,05 , yang artinya jumlah harga beras tidak signifikan atau tidak berpengaruh nyata terhadap konsumsi beras. Hal ini sejalan dengan penelitian Marzuki (2013) yang menyatakan bahwa kenaikan harga beras tidak berpengaruh pada konsumsi beras masyarakat Desa Suak Kecamatan Johan Pahlawan Kabupaten Aceh Barat.

Harga adalah kompensasi yang harus dilakukan untuk mendapatkan sejumlah barang dan jasa. Dalam menetapkan harga produk, produsen harus memperhitungkan biaya sehingga tidak terlalu tinggi atau rendah yang akan mempengaruhi konsumsen dan produsen sendiri dalam mendapatkan keuntungan (Arifin, 2007).

Harga jual adalah jumlah moneter yang dibebankan oleh suatu usaha kepada pembeli atau pelanggan atas barang dan jasa yang dijual atau diserahkan. Keputusan penentuan harga jual sangat penting, karena selain mempengaruhi laba yang ingin dicapai juga mempengaruhi kelangsungan hidup produsen. Oleh karena itu dalam menentukkan harga jual produk, tidak dapat dilakukan sekali saja tetapi harus selalu dievaluasi dan disesuaikan dengan kondisi yang dihadapi produsen. Selain itu harga adalah salah satu faktor yang dapat mengukur tingkat keberhasilan suatu usahatani, karena dapat menentukkan besar kecilnya penerimaan yang akan diterima oleh petani sampai dengan penentuan pendapatan yang akan diterima oleh petani.

3. Koefisien Determinasi

Uji koefisien determinasi yang digunakan untuk melihat kelayakan penelitian ini dengan melihat pengaruh variabel independent terhadap variabel dependent. Koefisien determinasi $\mathrm{R}^{2}$ digunakan untuk mengetahui berapa persen variasi variabel dependent dapat dijelaskan oleh variasi variabel independent. Berdasarkan hasil dugaan model dalam penelitian ini sangat baik karena nilai koefisien determinasi $\left(\mathrm{R}_{2}\right)$ persamaan struktural adalah 1,00 atau 100\%. Dengan demikian secara umum variabel-variabel independent yang ada dalam persamaan struktural mampu menjelaskan dengan baik variabel dependentnya. Bahwa 100\% konsumsi beras penduduk Kecamatan Praya Barat Kabupaten Lombok Tengah selama 10 tahun terakhir dipengaruhi oleh produksi beras, jumlah penduduk dan harga beras.

\section{KESIMPULAN DAN SARAN}

\section{Kesimpulan}

1. Jumlah produksi padi petani pemilik lahan di Kecamatan Praya Barat tergolong dalam kelas "klaster 2" lumbung pangan nasional yaitu luas panen rendah 0,418 dengan jumlah produksi sedang dengan produktivitas $52,51 \mathrm{kwintal} / \mathrm{Ha}$ pertahun yang jika dikonversikan ke beras menghasilkan $95.879 \mathrm{Kg}$ dengan rata-rata $1.245 \mathrm{~kg} / \mathrm{LLG}$ persatu kali musim tanam.

2. Rata-rata konsumsi beras petani pemilik lahan selama satu kali musim tanam di Kecamatan Praya Barat adalah $39,6 \mathrm{Kg} / \mathrm{kap} / 4$ bulan atau $118,8 \mathrm{Kg} / \mathrm{kapita} /$ tahun dan dikatagorikan kedalam kelas konsumsi sedang. Sedangkan faktor yang paling mempengaruhi konsumsi beras petani pemilik lahan di Kecamatan Praya Barat adalah jumlah anggota keluarga dengan tingkat kesalahan $1 \%$ atau pada taraf nyata $99 \%$. Sedangkan tingkat pendapatan tidak berpengaruh terhadap konsumsi beras petani pemilik lahan karena memiliki nilai probabilitas 0,189 yang lebih besar dari taraf nyata $(0,05)$.

Saran

1. Diharapkan kepada petani pemilik lahan supaya selalu mempertahankan bahakan meningkatkan produksi padi agar kebutuhan terhadap konsumsi beras selalu tercukupi.

2. Jumlah produksi beras yang tersisa sebaiknya dijual agar dapat menambah pendapatan rumah tangga petani pemilik lahan.

3. Diharpakan kepada pihak pemerintah untuk selalu mendukung petani dengan cara memberikan penyuluhan, bantuan seperti benih, pupuk dan obat-obatan supaya motivasi petani dalam menanam padi lebih giat sehingga dapat meningkatkan nilai produksi. 


\section{DAFTAR PUSTAKA}

Ilyas, 1998. Macam-macam Bentuk Keluarga Berdasarkan Jumlah tanggungan Keluarga. Binaputra Saputra. Jakarta

Iriyanti, N.S. 2017. Faktor-Faktor yang Mempengaruhi Konsumsi Beras di Kecamatan Berbak Kabupaten Tanjung Jabur Timur. Skripsi. Fakultas Pertanian. Universitas Jambi

Marzuki. 2013. Dampak Perubahan Harga Beras Terhadap Konsumsi Beras Pada Masyarakat Di Dusun III Desa Suak Ribe Kecamatan Johan Pahlawan Kabupaten Aceh Barat. Fakultas Pertanian. Universitas Teuku Umar.

Roza AM., dan Tamara NH. 2016. Provinsi Dominasi Produksi Padi Nasional. http://katadata.co.id/infografik/2016/08/09/3-provinsi-dominasi-produksi-padi-nasional

Septiadi, D. 2019. Analisis Respon dan Faktor-Faktor yang Mempengaruhi Permintaan Beras Indonesia. Agrimor: Jurnal Agribisnis Lahan Kering. Vol 4 (3) 2019: 42-44.

Septiadi, D. 2019a. Analisis Respon dan Faktor-Faktor yang Mempengaruhi Permintaan Beras Indonesia. Agrimor: Jurnal Agribisnis Lahan Kering. Vol 4 (3) 2019: 42-44.

Septiadi, D., Harianto, H., \& Suharno, S. 2016. Dampak Kebijakan Harga Beras dan Luas Areal Irigasi Terhadap Pengentasan Kemiskinan di Indonesia. Jurnal Agribisnis Indonesia, 4(2), 91. https://doi.org/10.29244/jai.2016.4.2.91-106

Soekartawi.2002. Prinsip Dasar Ekonomi Pertanian dan Aplikasinya. Rajawali. Jakarta

Soemarwoto, 2018. Catatan Penting Ke-Indonesia-An Kita. CV. Budi Utama. Yogyakarta.

Soeharjo., dan Patong. 1999. Sendi-Sendi Proyek Ilmu Usahatani. Departemen Ilmu-Ilmu sosial. IPB

Utama, M.Z.H. 2015. Budidaya Padi Pada Lahan Marjinal Kiat Meningkatkan Produksi Padi. CV. Andi Offset. Yogyakarta. 